\title{
Farklı Kesimhanelerden İzole Edilen Campylobacter Türlerinin Virülans Genleri, Antibiyotik Duyarlılık Profilleri ve Moleküler Karakterizasyonu
}

\section{Virulence Genes, Antibiotic Susceptibility Profiles and Molecular Characterization of Campylobacter Species Isolated from Different Slaughterhouses}

\author{
Harun HIZLISOY

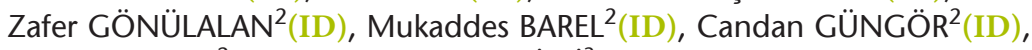

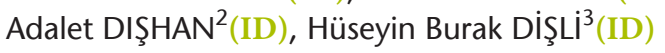 \\ ${ }^{1}$ Erciyes Üniversitesi Veteriner Fakültesi, Veteriner Halk Sağlığı Anabilim Dalı, Kayseri. \\ ${ }^{1}$ Erciyes University Faculty of Veterinary, Department of Veterinary Public Health, Kayseri, Turkey. \\ 2 Erciyes Üniversitesi Veteriner Fakültesi, Besin Hijyeni ve Teknolojisi Anabilim Dalı, Kayseri. \\ 2 Erciyes University Faculty of Veterinary, Department of Food Hygiene and Technology, Kayseri, Turkey. \\ ${ }^{3}$ Hatay Mustafa Kemal Üniversitesi Veteriner Fakültesi, Besin Hijyeni ve Teknolojisi Anabilim Dalı, Hatay. \\ ${ }^{3}$ Hatay Mustafa Kemal University Faculty of Veterinary, Department of Food Hygiene and Technology, Hatay, Turkey.
}

* Bu çalışma, VIII. Ulusal/II. Uluslararası Veteriner Gıda Hijyeni Kongresi (24-27 Ekim 2019, Antalya)’nde sunulmuştur.

Bu çalışmada, Kayseri bölgesinde üç farkı kesimhaneden kesim tahtası, kesimhane atık suyu, duvar, bıçak ve karkas örneklerinden; i) Campylobacter türlerinin araştırılması, ii) izolatların antibiyotik direnç durumları ile virülans genlerinin ortaya konması, iii) klonal yakınlıklarının belirlenmesi amaçlanmıştır. Bu amaçla, Kayseri'de 2018 yılında üç farklı kesimhaneden her bir örnek tipinden (bıçak, duvar, kesim tahtaSı, karkas sürüntü örneği ve kesimhane atık suyu) onar adet olmak üzere toplam 150 numune toplanmıştır. Campylobacter türlerinin izolasyonu amacıyla ön zenginleştirmeyi takiben süspansiyonlardan modifiye "charcoal cefoperazone desoxycholate (CCD)" agara ekim yapılmıştır. Besiyerinde gri-beyaz renkteki şüpheli koloniler seçilerek Gram boyama, oksidaz, katalaz ve hareket testi yapılmıştır. Campylobacter türlerinin moleküler tanımlanması amacıyla multipleks polimeraz zincir reaksiyonu (mPCR) uygulanmıştır. Tür düzeyinde tanımlanan izolatların antimikrobiyal duyarlılıkları disk difüzyon testi ve antibiyotik gradiyent test yöntemi kullanılarak belirlenmiştir. İzolatlarda virülans genleri (iam, cadF, cdtA, flaA, ceuE, cdtC, cdtB ve virB11) PCR ile incelenmiştir. Tür düzeyinde belirlenmiş izolatların moleküler tiplendirilmesi "Enterobacterial Repetitive Intergenic Consensus PCR (ERIC-PCR)" ile gerçekleştirilmiştir. Çalışmada, kesimhane ortamından alınan 150 örneğin 17 (\%11.3)'si Campylobacter spp. şüpheli bulunmuş ve izolatlara yapılan fenotipik tanımlama testleri sonucunda izolatların hepsi Campylobacter spp. olarak doğrulanmıştır. mPCR incelemesi sonunda izolatların, sekizi Campylobacter jejuni, sekizi Campylobacter fetus ve biri de Campylo- 
Farklı Kesimhanelerden İzole Edilen Campylobacter Türlerinin Virülans Genleri,

Antibiyotik Duyarlılık Profilleri ve Moleküler Karakterizasyonu

bacter coli olarak belirlenmiştir. Campylobacter türlerinin farklı kaynaklardan izolasyonunda, kesimhane atık suyundaki oranın, diğerlerinden daha yüksek olduğu $(p<0.001)$ ve farklı kaynaklardan elde edilen Campylobacter türlerinin oransal dağılımındaki farkın istatistiksel açıdan önemli olduğu belirlenmiştir $(p<$ 0.05). Disk difüzyon testi sonucu, C.jejuni izolatlarının tamamı siprofloksasine dirençli bulunurken, enrofloksasine direnç \%87.5, neomisine direnç \%25, amoksisilin-klavulanik asite direnç $\% 25$ ve eritromisine direnç \%12.5 olarak saptanmıştır. Ayrıca, C.fetus izolatlarının amoksisilin-klavulanik asit, neomisin ve gentamisine direnci sırasıyla \%25, \%25 ve \%12.5 olarak tespit edilmiştir. C.coli izolatında ise test edilen antibiyotiklere karşı direnç saptanmamıştır. Antibiyotik gradiyent test sonuçları ile disk difüzyon testi bulguları uyumlu bulunmuştur. İncelenen virülans genlerinden virB11, izolatların hiçbirinde tespit edilemezken, iam geni C.fetus ve C.coli izolatlarında bulunmamış, C.jejuni'de ise yalnız bir izolatta belirlenmiştir. C.jejuni izolatlarının altııında flaA geni tespit edilmiştir. C.coli izolatı ile yedişer C.jejuni ve C.fetus izolatı $c d t C$ geni yönünden pozitif bulunmuştur. $c d t A, c d t B$, ceuE ve $c a d F$ genleri, C.jejuni izolatlarının tamamında pozitif saptanmıştır. Çalışmada analiz edilen izolatların hepsi birbirinden farkı ERIC-PCR profili göstermiştir. Sonuç olarak, kesimhanelerden izole edilen Campylobacter izolatlarının güncel antibiyotiklerin birçoğuna dirençli olduğu ortaya konmuştur. Kesimhane ortamında yüksek virülans özelliklere sahip Campylobacter türlerinin bulunması, karkaslar ve dolayısıyla gıdalar vasıtasıyla insanlara etkenin bulaşma riskinden dolayı halk sağlı̆ı̆ını tehdit etmektedir. Bu nedenle, kesimhanelerde Campylobacter türleri ile kontaminasyonun azaltılması için hijyen kurallarına tam olarak uyulması gerekmektedir.

Anahtar kelimeler: Antibiyotik direnci; Campylobacter spp.; ERIC-PCR; kesimhane; virülans.

\section{ABSTRACT}

The aim of this study was to investigate the frequency of Campylobacter species, to detect the antibiotic resistance profiles and the virulence genes and to determine the clonal proximity of the isolates in the samples of cutting board, slaughterhouse waste water, wall, knife and carcass from three different slaughterhouses in Kayseri region. For this purpose, a total of 150 samples, 10 of each from knife, wall, cutting board, carcass smear sample and slaughterhouse wastewater were collected from each of the three types of slaughterhouses in 2018 in Kayseri. For the isolation of the Campylobacter species, following preenrichment, the suspensions were inoculated onto modified charcoal cefoperazone desoxycholate (CCD) agar and were incubated at $37^{\circ} \mathrm{C}$ under microaerophilic condition for $48-72$ hours. Suspicious colonies with gray-white color were recovered and subjected to phenotypical (Gram staining, oxidase, catalase test, and motion test) tests. Multiplex polymerase chain reaction (mPCR) was used for the molecular identification of the Campylobacter species. Antimicrobial susceptibilities of the isolates identified at the species level were detected by using the disk diffusion test and antibiotic gradient test. Virulence genes (iam, $c a d F, c d t A$, flaA, ceuE, $c d t C, c d t B$ and virB11) among the isolates were evaluated by PCR. The molecular typing of the isolates determined at species level was performed by Enterobacterial Repetitive Intergenic Consensus PCR (ERIC-PCR). In the study, 17 (11.3\%) of the 150 samples taken from the slaughterhouse were found to be suspicious in terms of Campylobacter spp. and as a result of phenotypic identification tests, all of the isolates were verified as Campylobacter spp.. As a result of MPCR; eight of the isolates were identified as Campylobacter jejuni, eight as Campylobacter fetus and one as Campylobacter coli. The isolation of the Campylobacter species from different sources was found to be higher in slaughterhouse wastewater than those of others $(p<0.001)$ and the difference in the proportional distribution of the Campylobacter species obtained from various sources was statistically significant $(p<0.05)$. As a result of the disk diffusion test, while, all C.jejuni isolates were resistant to ciprofloxacin, $87.5 \%, 25 \%, 25 \%$ and $12.5 \%$ of C.jejuni isolates were resistant to enrofloxacin, neomycin, amoxicillin/clavulanic acid, and erythromycin, respectively. In addition, 25\%, $25 \%$ and $12.5 \%$ of C.fetus isolates were resistant to amoxicillin/clavulanic acid, neomycin and gentamicin, respectively. C.coli isolate was not resistant to any of the antibiotics tested. Antibiotic gradient test results were found to be compatible with the disc diffusion test results. One of the virulence genes examined, virB11, was not detected in any of the isolates. Moreover, iam gene was not present in C.fetus and C.coli isolates, but only in one C.jejuni isolate. The flaA gene was detected in six C.jejuni isolates. C.coli isolate and seven C.jejuni and seven C.fetus isolates were positive in terms of the $c d t C$ gene. The $c d t A, c d t B$, ceuE and cadF genes were found to be positive in all C.jejuni isolates. All isolates analyzed in the study demonstrated different ERIC-PCR profiles. In conclusion, it was shown that Campylobacter strains isolated from slaugh- 
terhouses were resistant to the most of the current antibiotics. Moreover, the presence of highly virulent Campylobacters in the slaughterhouse environment threatens public health due to the risk of contamination of the humans via carcasses and foods. Therefore, it is recommended that strict hygiene rules should be followed to reduce Campylobacter species contamination in slaughterhouses.

Keywords: Antibiotic resistance; Campylobacter spp.; ERIC-PCR; slaughterhouse; virulence.

\section{Giriş}

Gıda kaynaklı gastroenterit olguları genellikle Salmonella spp., Staphylococcus aureus, Listeria monocytogenes, Campylobacter spp. ve Escherichia coli 0157:H7 gibi patojen bakterilerden kaynaklanmaktadır ${ }^{1}$. Bunlar arasında Campylobacter spp. ise dünya genelinde insanlarda görülen gıda kaynaklı bakteriyel hastalıkların en yaygın etkeni olarak rapor edilmektedir ${ }^{2}$. Campylobacter türleri, gıda amacıyla üretilen hayvanlar ve insanlar arasında çeşitli yollarla bulaş gösterebilmektedir ${ }^{3}$. Farklı çalışmalarda, kanatlı etlerinde, yüksek düzeyde Campylobacter türlerinin varlığı ortaya konulsa da, sığır ve koyun gibi çiftlik hayvanlarının sindirim sistemlerinin, Campylobacter türleri için uygun bir yaşam alanı oluşturduğu bildirilmektedir ${ }^{4}$. Campylobacter türleri, bu sayede insanlarda ve hayvanlarda gastrointestinal ve genital enfeksiyonlara neden olabilmektedir ${ }^{5}$.

Campylobacter türleri, insan organizmasına kontamine etlerin tüketimi veya asemptomatik hayvanlardan hazırlanan hayvansal ürünler vasıtası ile giriş yapabilmektedir. Campylobacter türleri, kesim, işleme, depolama ve son olarak sofraya kadar ki her aşamada gıdaları kontamine edebilmektedir ${ }^{1}$. Campylobacter türlerinin neden olduğu birçok enfeksiyon kendini sınırlayıcı özelliktedir ve hastalar genellikle tedaviye gerek kalmadan iyileşebilmektedir. Ancak septisemi, Guillain-Barre sendromu (GBS), irritabl bağırsak sendromu (IBS) ve reaktif artrit (RA) gibi komplike durumlar da oluşabilmektedir ${ }^{5}$.

Campylobacter türlerinin neden olduğu enfeksiyonlarda klinik semptomların çeşitliliğinde konak yanıtına ek olarak etkenin patojenik karakteri de rol oynamaktadır. Bu duruma neden olan hareket, konak hücre adezyonu/invazyonu, hücre ölümü, konak savunmasından kaçış gibi mekanizmalar ve birçok gen bulunmaktadır². Bunlar flaA (flajella proteini A), $\operatorname{cadF}$ (bakterinin fibrinonektine adezyonuna neden olan gen), virB1 1 (yapışma ve kolonizasyon geni), ciaB (invazyon antijeni), $c d t A B C$ (sitoletal genişleten toksin $A ; B ; C)$, cgtB (GBS ile ilişkili gen) genleridir 6 .

Bu çalışmada, Kayseri bölgesinde hizmet veren üç farklı kesimhanede karkaslar ile kesimhane ortamına ait çeşitli örneklerde Campylobacter türlerinin araştırılması, tanımlanan izolatların antibiyotik direnç profillerinin ve virülans genlerinin ortaya konulması ve bunun yanı sıra izolatların klonal yakınlıklarının belirlenerek kontaminasyon varlığının saptanması amaçlanmıştır.

\section{GEREÇ ve YÖNTEM}

\section{Örneklerin Toplanması}

Bu çalışmada, Haziran-Ağustos 2018 döneminde Kayseri ilinde bulunan ve şehir merkezine yaklaşık 7 km uzaklıkta yer alan Karpuzatan mevkiinde, özellikle büyükbaş hayvan- 
Farklı Kesimhanelerden İzole Edilen Campylobacter Türlerinin Virülans Genleri,

Antibiyotik Duyarlıık Profilleri ve Moleküler Karakterizasyonu

\begin{tabular}{|lcccc|}
\hline \multicolumn{5}{|l}{ Tablo I. Çalışma Kapsamında Kesimhanelerden Toplanan Örnek Çeşitleri ve Sayıları } \\
\hline Örnek & Kesimhane $\mathbf{1}$ & Kesimhane 2 & Kesimhane 3 & Toplam \\
\hline Kesim tahtası & 10 & 10 & 10 & 30 \\
Bıçak & 10 & 10 & 10 & 30 \\
Duvar & 10 & 10 & 10 & 30 \\
Atık suyu & 10 & 10 & 10 & 30 \\
Karkas & 10 & 10 & 10 & 30 \\
Toplam & 50 & 50 & 50 & 150 \\
\hline \multicolumn{5}{l}{} \\
\hline
\end{tabular}

ların kesiminin yapıldığı, rastgele seçilen üç farklı kesimhaneden, iki hafta arayla toplam 150 adet numune toplandı (Tablo I). Karkas, bıçak, duvar ve kesim tahtası yüzeylerinden örnek almak için Cary-Blair transport besiyeri (Oxoid, CM0519, İngiltere) kullanıldı. Kesimhane atık suyu örnekleri, kesimi takiben aseptik koşullarda, steril plastik tüpler içerisinde $30 \mathrm{ml}$ hacminde temin edildi. Karkastan örnek alımında seçilen her bir yarım karkasın değişik bölgelerinden (but, kavram ve döş) $10 \times 10 \mathrm{~cm}\left(100 \mathrm{~cm}^{2}\right)$ ebadında, steril plastik template $\left(10 \times 10^{\prime}\right.$ luk) kullanılarak, 10 adet horizontal ve 10 adet vertikal sürtme hareketi ile karkas yüzeyine eşit basınç uygulamaya dikkat ederek alınan steril sürüntü örnekleri Cary-Blair besiyeri içeren tüplere konuldu. Toplanan örnekler, soğuk zincirde laboratuvara getirilerek aynı gün içerisinde incelemeye alındı.

\section{Campylobacter spp. İzolasyonu ve Tür Düzeyinde Tanımlama}

Kesimhane örneklerinden Campylobacter spp.'lerin izolasyonu için ISO 10272 yönteminden yararlanıldı ${ }^{7}$. İzolasyonda ilk olarak ön zenginleştirme işlemi yapıldı. Bu amaçla besiyeri olarak, Bolton buyyon zenginleştirme besiyeri (Oxoid CM0983, İngiltere) ve modifiye "charcoal cefoperazone desoxycholate (mCCD)" agar (Oxoid CM739, Ingiltere) kullanıldı. Örnekler Bolton buyyon (Lize at kanı eklenmiş) besiyeri içeren tüplere ve "stomacher" poşetlerine konuldu. Daha sonra homojen hale getirilerek mikroaerofil ortamda $37^{\circ} \mathrm{C}^{\prime}$ de 48 saat inkübe edildi. İnkübasyon sonunda ön zenginleştirme yapılan sıvı kültürden $0.1 \mathrm{ml}$ alınarak CCDA (Oxoid SR0155, İngiltere) supplementi ilave edilmiş seçici besiyerine (modifiye CCD Agar, Oxoid CM739, İngiltere) ekimler yapıldı. Daha sonra, petriler $37^{\circ} \mathrm{C}^{\prime}$ de mikroaerofil ortamda (Anaerocult C, Merck, M116275.0001, Almanya) 48-72 saat inkübe edildi. Besiyerinde gri-beyaz renkteki şüpheli koloniler izole edilerek, fenotipik (Gram boyama, oksidaz, katalaz ve hareket testi) testlere tabi tutuldu. Fenotipik yönden pozitif bulunan izolatlar \%10 gliserinli (Merck, M1040942500, Almanya) Brucella buyyon (Oxoid, CM0169, Ingiltere) içeren kriyotüplere alınarak, sonraki testler için numaralandırılıp, etiketlendi ve $-80^{\circ} \mathrm{C}^{\prime}$ deki derin dondurucuda muhafaza edildi.

Campylobacter spp. izolatlarının moleküler tanımlaması amacıyla öncelikle izolatlardan DNA ekstraksiyonu yapıldı. Bu amaçla InstaGene ${ }^{T M}$ Matrix (Bio-Rad, ABD) kitinden yararlanıldı. İzolatlar, üretici firmanın direktifleri doğrultusunda ekstraksiyon işlemine tabi 
tutuldu. DNA örneklerinin konsantrasyonları $(\mu \mathrm{g} / \mu \mathrm{l})$ Qubit 3.0 florometre (Thermo Fisher, $A B D$ ) ile ölçülüp, analiz edilinceye kadar $-20^{\circ} \mathrm{C}^{\prime}$ de saklandı. Campylobacter türlerinin moleküler tanımlaması amacıyla Wang ve arkadaşlarının ${ }^{8}$ bildirdiği multipleks polimeraz zincir reaksiyonu (mPCR) koşulları ve primerler (Tablo II) ve pozitif kontrol amacıyla Campylobacter jejuni ATCC 700819 izolatı kullanıldı. Bu amaçla, her numune için toplam hacim $25 \mu$ l olacak şekilde bir reaksiyon karışımında; $2.5 \mu$ l DNA örneği, 1x PCR

\begin{tabular}{|c|c|c|}
\hline Primer & Baz dizilim 5'- 3' & Bant büyüklüğü (bp) \\
\hline \multirow[t]{2}{*}{ C.jejuni } & F- 5'- АCT TCT TTA TTG CTT GCT GC - $3^{\prime}$ & 323 \\
\hline & R- 5'- GCC ACA ACA AGT AAA GAA GC - 3' & \\
\hline \multirow[t]{2}{*}{ C.coli } & F- 5'- GTA AAA CCA AAG CTT ATC GTG -3' & 126 \\
\hline & R- 5'- TCC AGC AAT GTG TGC AAT G -3' & \\
\hline \multirow[t]{2}{*}{ C.lari } & F- 5'- TAG AGA GAT AGC AAA AGA GA -3' & 251 \\
\hline & R- 5'- TAC ACA TAA TAA TCC CAC CC - $3^{\prime}$ & \\
\hline \multirow[t]{2}{*}{ C.upsaliensis } & F- 5'- AAT TGA AAC TCT TGC TAT CC - $3^{\prime}$ & 204 \\
\hline & R- 5'- TCA TAC ATT TTA CCC GAG CT -3' & \\
\hline \multirow[t]{2}{*}{ C.fetus } & F- 5'- GCA AAT ATA AAT GTA AGC GGA GAG -3' & 435 \\
\hline & R- 5'- TGC AGC GGC CCC ACC TAT -3' & \\
\hline \multirow[t]{2}{*}{ 23SrRNA } & F- 5'- TAT ACC GGT AAG GAG TGC TGG AG -3' & 650 \\
\hline & R- 5'- ATC AAT TAA CCT TCG AGC ACC G -3' & \\
\hline \multirow[t]{2}{*}{ flaA } & F- 5'- ATG GGA TTT CGT ATT AAC AC -3' & 1700 \\
\hline & R- 5'- CTG TAG TAA ATC TTA AAA CAT TTT G - $3^{\prime}$ & \\
\hline \multirow[t]{2}{*}{$c d t A$} & F- 5'- GGA AAT TGG ATT TGG GGC TAT ACT -3' & 165 \\
\hline & R-5'- ATC ACA AGG ATA ATG GAC AAT -3' & \\
\hline \multirow[t]{2}{*}{$c d t B$} & F- 5'- GTT AAA ATC CCT GCT ATC AAC CA -3' & 495 \\
\hline & R- 5'- GTT GGC ACT TGG AAT TTG CAA GGC -3' & \\
\hline \multirow[t]{2}{*}{$c d t C$} & F- 5'- TGG ATG ATA GCA GGG GAT TTT AAC - $3^{\prime}$ & 555 \\
\hline & R- 5'- TTG CAC ATA ACC AAA AGG AAG -3' & \\
\hline \multirow[t]{2}{*}{$\operatorname{virB11}$} & F- 5'- TCT TGT GAG TTG СCT TAC CCC TTT T -3' & 494 \\
\hline & R- 5'- CCT GCG TGT CCTGTGTTATTTACCC -3' & \\
\hline \multirow[t]{2}{*}{ ceuE } & F- 5'- CCT GCT CGG TGA AAG TTT TG - $3^{\prime}$ & 794 \\
\hline & R- 5'- GAT CTT TTT GTT TTG TGC TGC - $3^{\prime}$ & \\
\hline \multirow[t]{2}{*}{ CadFR1B } & F- 5'- TTG AAG GTA ATT TAG ATA TG -3' & 400 \\
\hline & R- 5'- CTA ATA CCT AAA GTT GAA AC - $3^{\prime}$ & \\
\hline \multirow[t]{2}{*}{ iam } & F-5'- GCG CAA AAT ATT ATC ACC C -3 & 518 \\
\hline & R- 5'- TTC ACG ACT ACT ATG CGG -3' & \\
\hline ERIC-I & 5'- ATG TAA GCT CCT GGG GAT TCA C - $3^{\prime}$ & - \\
\hline ERIC-II & 5'- AAG TAA GTG ACT GGG GTG AGC G -3' & - \\
\hline
\end{tabular}


tamponu (Thermo Scientific, ABD), $20 \mathrm{mM} \mathrm{MgCl}_{2}$ (Vivantis, Malezya), $0.2 \mathrm{mM}$ dNTP karışımı (Thermo Scientific, ABD), $0.5 \mu \mathrm{M}$ C.jejuni ve C.lari; $1 \mu \mathrm{M}$ C.coli ve C.fetus, $2 \mu \mathrm{M}$ C.upsaliensis, $0.2 \mu \mathrm{M}$ Campylobacter 23S rRNA primerleri ve 1.25 U Taq polimeraz (Thermo Scientific, ABD) olarak hazırlandı. DNA amplifikasyonu $95^{\circ} \mathrm{C}^{\prime}$ de 6 dakika başlangıç denatürasyonu takiben 30 döngü olmak üzere, $95^{\circ} \mathrm{C}^{\prime}$ de 30 saniye denatürasyon, $59^{\circ} \mathrm{C}^{\prime} \mathrm{de}$ 30 saniye primer bağlanması ve $72^{\circ} \mathrm{C}^{\prime}$ de 30 saniye uzama ve en son $72^{\circ} \mathrm{C}^{\prime}$ de 7 dakika son uzama olarak ısı döngü cihazı (Arktic ${ }^{\mathrm{TM}}$ Termal Cycler; Thermo Fisher, ABD)'nda gerçekleştirildi. Amplifikasyon sonucunda elde edilen PCR ürünleri, \%1.5 agaroz jelde 90 V'da 90 dakika boyunca elektroforez cihazında yürütüldükten sonra (Thermo EC 330, ABD) UVP jel dokümantasyon sistemi (Vilber Lourmat, Fransa) kullanılarak görüntülendi. Çalışmada yer alan örneklerde saptanan Campylobacter türleri bant büyüklüklerine göre tanımlandı (Tablo II).

\section{Antibiyotik Duyarlılık Testi}

Campylobacter spp. olarak tanımlanmış izolatların gentamisin ( $\mathrm{CN}, 10 \mu \mathrm{g})$, amoksisilin-klavulanik asit (AMC, $30 \mu \mathrm{g})$, neomisin (N, $10 \mu \mathrm{g})$, enrofloksasin (ENR, $5 \mu \mathrm{g}$ ), eritromisin $(E, 15 \mu \mathrm{g})$, siprofloksasin (CIP, $5 \mu \mathrm{g}$ ), doksisiklin (DO, $30 \mu \mathrm{g}$ ) (Oxoid, İngiltere) antibiyotiklerine karşı duyarlılıkları, disk difüzyon testi ile belirlendi. İzolatlar \%5 defibrine koyun kanlı agarda mikroaerofil ortamda $37^{\circ} \mathrm{C}^{\prime}$ de $24-48$ saat süreyle inkübe edildi ve üreyen koloniler \%0.075 NaCl çözeltisi içinde süspanse edildi. Bakteri yoğunluğu 0.5 McFarland bulanıklık standardına göre ayarlandıktan sonra $0.1 \mathrm{ml}$ hacimde kanlı agara inoküle edildi ve antibiyotik duyarlılık test diskleri besiyeri üzerine yerleştirildi. Petriler, mikroaerofil ortamda $37^{\circ} \mathrm{C}^{\prime}$ de $24-48$ saat inkübasyona bırakıldı. Test sonunda oluşan inhibisyon zon çapları ölçülerek "Clinical and Laboratory Standards Institute (CLSI)" önerilerine göre değerlendirildi" . Çalışmada kontrol suşlar olarak S.aureus ATCC 25923, E.coli ATCC 25922 ve C.jejuni ATCC 700819 kullanıldı.

\section{Antibiyotik Gradiyent Testi}

Campylobacter spp. izolatlarının gentamisin, amoksisilin-klavulanik asit, enrofloksasin, eritromisin, siprofloksasin, doksisiklin (Liofilchem, İtalya) antibiyotiklerine karşı minimum inhibitör konsantrasyonu (MiK) değerleri antibiyotik gradiyent test yöntemi ile belirlendi. C.jejuni, C.fetus ve C.coli izolatlarının taze kültürü 0.5 McFarland yoğunluğuna getirilerek kanlı agar yüzeyine eküvyonla yayıldı. Agar yüzeyine yerleştirilen antibiyotik gradiyent şeritleri sonrasında besiyerleri $37^{\circ} \mathrm{C}^{\prime}$ de 48 saat mikroaerofil ortamda inkübe edildi. Elde edilen sonuçlar CLSI önerilerine göre değerlendirildi ${ }^{9}$.

\section{Virülans Genlerinin PCR ile Gösterilmesi}

Virülans genlerin (iam, $c a d F, c d t A, f l a A, c e u E, c d t C, c d t B$ ve virB11) varlığı daha önceki çalışmalarda belirtilen yöntemlere göre küçük değiş̧iklikler yapılarak PCR tekniği ile belirlendi ${ }^{6,10-12}$. Reaksiyon karışımı; $4 \mu$ l kalıp DNA, KCl eklenmiş 1x PCR tamponu (Thermo Scientific, ABD), $1.5 \mathrm{mM} \mathrm{MgCl}_{2}$ (Vivantis, Malezya), $250 \mathrm{mM}$ dNTP karışımı (Thermo Scientific, $A B D$ ), her bir primerden $1 \mu \mathrm{M}$ and $0.5 \mathrm{U}$ Taq polimeraz (Thermo Scientific, ABD) 


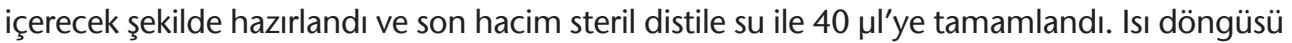
$94^{\circ} \mathrm{C}^{\prime}$ de 1 dakika ön denatürasyonu takiben 30 döngü $52^{\circ} \mathrm{C}^{\prime}$ de 1 dakika primer bağlanması ve $72^{\circ} \mathrm{C}^{\prime}$ de 1 dakika uzama basamağı bulundu. Son olarak, $72^{\circ} \mathrm{C}^{\prime}$ de 5 dakika son uzama basamağı yer aldı. PCR ürünleri bir saat boyunca 100 V'da $\% 1.5$ (a/h) TAE agaroz jelinde elektroforez cihazında (Thermo EC 330, ABD) yürütüldü. Agaroz jel, UVP jel görüntüleme sistemi (Vilber Lourmat, Fransa) kullanılarak PCR ürünlerine ait bantlar görüntülendi.

\section{Campylobacter spp. İzolatlarının "Enterobacterial Repetitive Intergenic Consensus (ERIC)" PCR ile Moleküler Tiplendirilmesi}

Çalışmada izole edilen Campylobacter türlerinin moleküler tiplendirilmesi için Houf ve arkadaşlarının ${ }^{13}$ bildirdiği ERIC-PCR yöntemi kullanıldı. Amplifikasyon için PCR karışımı; 5 ul 10x PCR tampon A (Thermo Scientific, ABD), $4 \mathrm{mM} \mathrm{MgCl}_{2}$ (Vivantis, Malezya), 5 U Taq DNA polimeraz (Thermo Scientific, ABD), son konsantrasyonu $0.2 \mathrm{mM}$ olacak şekilde dNTP karısımı (Thermo Scientific, ABD), 25 pmol her bir primer (Sentromer DNA Teknolojileri, istanbul, Türkiye) ve $1 \mu \mathrm{l}$ kalıp DNA içeren toplam $50 \mu \mathrm{l}$ hacimde hazırlandı. Amplifikasyon $94^{\circ} \mathrm{C}^{\prime}$ de 5 dakika ön denatürasyonu takiben 40 döngü $94^{\circ} \mathrm{C}^{\prime}$ de 1 dakika denatürasyon, $25^{\circ} \mathrm{C}^{\prime}$ de 1 dakika bağlanma ve $72^{\circ} \mathrm{C}^{\prime}$ de 2 dakika uzama şeklinde gerçekleştirildi. Elde edilen PCR ürünleri, \%2'lik agaroz jelde yürütüldü (Thermo EC 330, ABD) ve oluşan bantlar jel dokümantasyon sisteminde (Vilber Lourmat, Fransa) incelendi. UPGMA algoritması, bant paternlerinin küme analizi için kullanıldı ${ }^{14}$. Filogenetik ağaç, iTOL versiyon 4 kullanılarak ortaya çıkarıldı ${ }^{15}$. Normalleştirmeden sonra, en üst pozisyona dayalı profil benzerlikleri, 100 tekrarlı olarak Jaccard benzerlik katsayısı kullanılarak hesaplandı. Çalışmada izole edilen yalnız bir C.coli izolatı olması nedeniyle, dendogram tür temelli olarak yapılmamış, izole edilen tüm Campylobacter türleri bir arada değerlendirilmiştir.

\section{İstatistiksel Analiz}

Çalışmada istatistiksel analiz için SPSS 14.01 paket programı kullanıldı. Çalışmada, Campylobacter türlerinin farklı kaynaklardan izolasyonunda pozitiflik oranları ve farklı kaynaklardan elde edilen Campylobacter türlerinin, türler arasında oransal dağılımının istatistiksel karşılaştırmalarında ki-kare $\left(\mathrm{X}^{2}\right)$ testi kullanıldı ${ }^{16}$.

\section{BULGULAR}

Çalışmada, kesimhane ortamından alınan 150 örneğin 17 (\%11.3)'si Campylobacter spp. varlığı yönünden pozitif bulunmuştur. Bu 17 pozitif örnekten yapılan fenotipik tanımlama testler ile 17 Campylobacter spp. izolatı elde edilmiştir. Moleküler tanımlama testleri sonunda 17 izolatın, sekizi C.jejuni, sekizi C.fetus ve biri de C.coli olarak belirlenmiştir. Campylobacter türlerinin farkı kaynaklardan izolasyonunda pozitiflik oranlarının istatistiksel karşılaştırılmasında, kesimhane atık suyundaki oranının diğer kaynaklardan daha yüksek olduğu belirlenmiş̧ir $(p<0.001)$. Farklı kaynaklardan elde edilen Campylobacter türlerinin oransal dağılımı açısından istatistiksel fark önemli bulunmuştur $(p<0.05)$. Buna göre, C.jejuni ve C.fetus'un görülme oranı birbirleriyle eşit, C.coli'ye göre daha yüksek olduğu tespit edilmiştir. İzolatların kesimhane ortamındaki dağııımı Tablo III'te detaylı olarak verilmiştir. 
Farklı Kesimhanelerden İzole Edilen Campylobacter Türlerinin Virülans Genleri,

Antibiyotik Duyarlılık Profilleri ve Moleküler Karakterizasyonu

\begin{tabular}{|c|c|c|c|c|c|}
\hline Campylobacter spp. & Atık su & Duvar & Karkas & Biçak & Tahta \\
\hline C.jejuni & 6 & 1 & - & 1 & - \\
\hline C.fetus & 4 & 1 & 2 & - & 1 \\
\hline C.coli & 1 & - & - & - & - \\
\hline
\end{tabular}

Disk difüzyon testi sonucu, izolatların kullanılan antibiyotiklere duyarlılıkları tür düzeyinde detaylı bir şekilde Tablo IV'te belirtilmiştir. Buna göre, C.jejuni izolatlarının tamamı gentamisin, neomisin ve doksisikline duyarlıyken, C.fetus izolatlarının tamamı sadece doksisikline duyarlı bulunmuştur. C.coli izolatı test edilen antibiyotiklere karşı dirençli değilken eritromisin, gentamisin, amoksisilin-klavulanik asit, neomisin ve doksisikline duyarlı saptanmıştır. C.jejuni izolatlarının tamamı siprofloksasine dirençli olarak tespit edilmiştir. Antibiyotik gradiyent test sonuçları disk difüzyon testi bulguları ile uyumlu bulunmuştur. MiK aralıkları eritromisin, gentamisin, amoksisilin-klavulanik asit, siprofloksasin, enrofloksasin ve doksisiklin antibiyotikleri için sırasıyla $0.12-16 \mu \mathrm{g} / \mathrm{ml}, 0.5-4 \mu \mathrm{g} / \mathrm{ml}, 0.5-64 \mu \mathrm{g} / \mathrm{ml}$, $0.25-32 \mu \mathrm{g} / \mathrm{ml}, 0.25-16 \mu \mathrm{g} / \mathrm{ml}$ ve $0.5-4 \mu \mathrm{g} / \mathrm{ml}$ olarak bulunmuştur.

Çalışmada elde edilen izolatların virülans genlerine ilişkin sonuçları Tablo V'te özetlenmiştir.

İzolatların genetik yönden yakınlıklarının belirlenmesi amacıyla yapılan ERIC-PCR ile Campylobacter spp. izolatlardan elde edilen bant profillerinin birbirinden farklılık gösterdiği saptanmıştır. Bant sayısının 2 ile 11 arasında değiştiği belirlenmiştir. Çalışmamızda küme analizi yapılmamış ve izolatların bant profilleri şematik olarak gösterilmiştir. Çaıışmada analiz edilen izolatların hepsi farklı ERIC-PCR profilleri göstermiş ve izolatların benzerlik durumlarına göre klonal yakınlıkları filogenetik ağaçta sunulmuştur (Şekil 1).

\section{TARTIŞMA}

Campylobacter türleri başlıca hayvan kaynaklı kontamine yiyeceklerle insanlara bulaşmaktadır. Gıdaların bu bakteri ile kontamine olması, gıda üretimi prosesi sırasında özellikle kesimhanelerde üretim, işleme, dağıtım ve hazırlık sırasında ortaya çıkabilmektedir. Kesimhanelerde gıda patojenleriyle kontamine olmuş sonrasında yetersiz ısıl işlem uygulanmış et ürünlerinin insanlar tarafından tüketilmesi Campylobacter enfeksiyonlarının gelişmesinde risk faktörü olarak belirlenmiştir ${ }^{1,3}$. Bu çalışmada, Kayseri yöresinde hizmet vermekte olan kesimhanelerden toplanan 150 örneğin 17 (\%11.3)'si Campylobacter spp. yönünden pozitif bulunmuştur. Yapılan fenotipik ve moleküler tanımlama testleri sonunda 17 izolatın, sekizi C.jejuni, sekizi C.fetus ve biri C.coli olarak tanımlanmıştır.

Wieczorek ve Osek'in çalışmalarında ${ }^{17}$ incelenen 191 sığır karkas sürüntü örneğinin 28 (\%14.7)'inde Campylobacter yönünden pozitiflik saptanmıştır. Bu çalışmada C.jejuni ve C.coli izolasyon oranı sırasıyla \%57.1 ve \%42.9 olarak tespit edilmiştir. Wieczorek ve arka- 


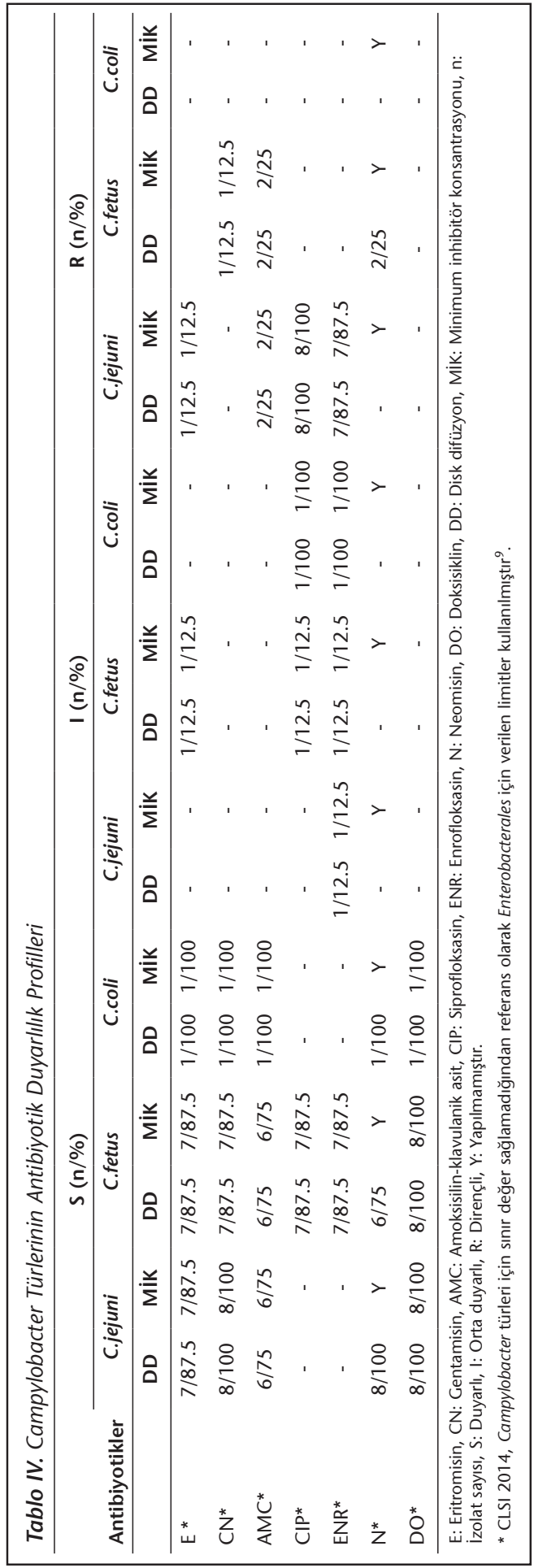




\begin{tabular}{|llllllllllll|}
\hline \multicolumn{7}{l}{ Tablo V. Campylobacter Türlerinde Virülans Genlerinin Dağılımı } \\
\hline Örnek & mPCR & flaA & cdtA & ceuE & cdtB & iam & virB11 & cdtC & cadF & Toplam \\
\hline 1 & C.jejuni & + & + & + & + & + & - & + & + & $7 / 8$ \\
2 & C.jejuni & + & + & + & + & - & - & + & + & $6 / 8$ \\
3 & C.jejuni & + & + & + & + & - & - & + & + & $6 / 8$ \\
4 & C.jejuni & + & + & + & + & - & - & + & + & $6 / 8$ \\
5 & C.jejuni & - & + & + & + & - & - & - & + & $4 / 8$ \\
6 & C.jejuni & + & + & + & + & - & - & + & + & $6 / 8$ \\
7 & C.jejuni & + & + & + & + & - & - & + & + & $6 / 8$ \\
8 & C.jejuni & - & + & + & + & - & - & + & + & $5 / 8$ \\
9 & C.fetus & - & + & + & - & - & - & + & - & $3 / 8$ \\
10 & C.fetus & - & + & + & + & - & - & + & + & $5 / 8$ \\
11 & C.fetus & - & - & - & + & - & - & - & - & $1 / 8$ \\
12 & C.fetus & - & + & + & + & - & - & + & - & $4 / 8$ \\
13 & C.fetus & - & - & + & + & - & - & + & - & $3 / 8$ \\
14 & C.fetus & - & - & + & + & - & - & + & + & $4 / 8$ \\
15 & C.fetus & - & - & + & + & - & - & + & - & $3 / 8$ \\
16 & C.fetus & - & + & + & + & - & - & + & - & $4 / 8$ \\
17 & C.coli & - & + & + & + & - & - & + & + & $5 / 8$ \\
Toplam & 17 & $6 / 17$ & $13 / 17$ & $16 / 17$ & $16 / 17$ & $1 / 17$ & - & $15 / 17$ & $11 / 17$ & \\
\hline mPCR: Multipleks polimeraz zincir reaksiyonu. & & & & & & & \\
\hline
\end{tabular}

daşlarının çalışmalarında ${ }^{18} 812$ sığır derisi ve karkas örneklerinden toplam 115 (\%14.2) Campylobacter izolatı elde edilmiştir. Bu çalışmada karkastan izole edilen türlerin \%63.6'sı C.jejuni, \%36.4'ü ise C.coli olarak tanımlanmıştır. Farklı olarak, Rahimi ve arkadaşları ${ }^{19}{ }^{1}$ ise inceledikleri karkas örneklerinin hiçbirinde Campylobacter türünü tespit edememişlerdir. Bulgular arası farklılıkların, incelenen hayvanın cinsi, hayvanın yaşı, mevsimsel fark, örnekleme sahası, örneklem sıklığı ve izolasyon yöntemi, coğrafya, diyet ve hayvancilık uygulamaları gibi değişkenlerden kaynaklandığı düşünülmektedir ${ }^{20}$. Wieczorek ve Osek ${ }^{17}$ ile Wieczorek ve arkadaşlarının ${ }^{18}$ yaptıkları çalışmalarda Campylobacter spp. prevalansının bu çalışmada elde edilen değerden daha yüksek olduğu gösterilmiştir. Bu farklıı̆̆ın nedeni, sadece karkas örneği alınmayıp ek olarak kesimhane ortamından da örnek toplanmış olmasına bağlı ortaya çıkan örnek çeşitliliği olabileceği düşünülmüştür.

Veteriner hekimlikte Campylobacter türleri arasında en önemli tür C.fetus'tur. C.fetus, sığır ve koyunlarda abortus ve kısırlık gibi üreme bozukluklarının potansiyel etkenidir ${ }^{20}$. Gastrointestinal semptomların \%90'ı C.jejuni ve C.coli kaynaklıdır. Buna karşılık, C.fetus, \%19-\%53 oranı ile Campylobacter kaynaklı bakteriyeminin en yaygın nedenidir. Bu tür invaziv C.fetus enfeksiyonlarında ölüm oranları da yaklaşık \%14 civarındadır ve dünya genelindeki yüksek Campylobacter enfeksiyonlarının insidansı göz önüne alındığında, bu 


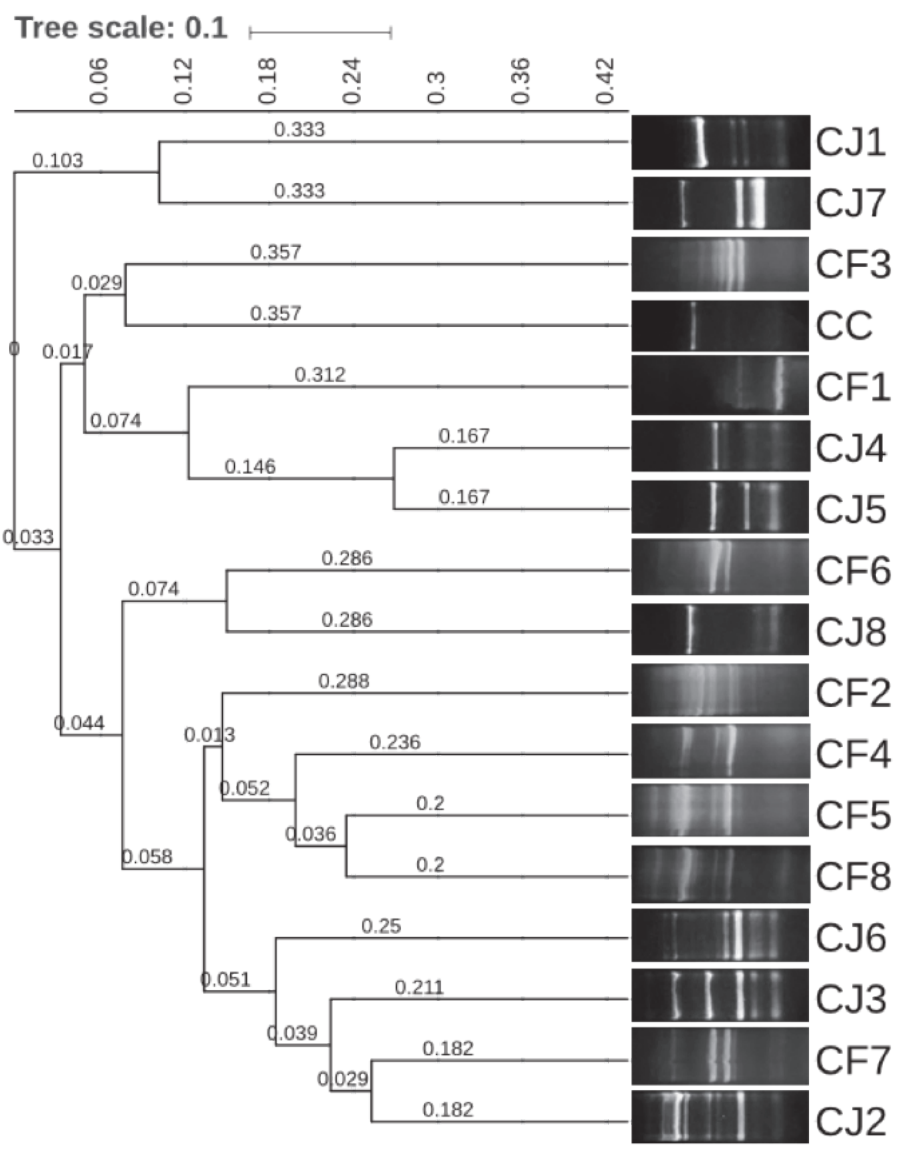

Şekil 1. C.jejuni, C.fetus ve C.coli izolatlarının filogenetik ağaç görüntüsü. C): C.jejuni, CF: C.fetus, CC: C.coli.

veriler C.fetus enfeksiyonlarının pek de nadir olmadığını ve halk sağlığı açısından oldukça önemli olduğunu vurgulamaktadı2 ${ }^{21}$. Çalışmamızda elde edilen C.fetus izolatlarının 2 (\%1.2)'si karkas kaynaklıdır. Bu durum, C.fetus izolatlarının kesimhane ortamında karkaslara kontamine olduğunu ve potansiyel bir enfeksiyon odağı haline geldiğini göstermektedir.

Kesimhanelerde atık su, esas olarak; sığır ve koyunların derilerinin yüzülmesinden, nakil sonrası karkasların yıkanmasından, ekipman ve tesislerin temizlenmesi ve sterilizasyonundan, mekanik ekipmanın soğutulması vs. işlemleri sonucu ortaya çıkmaktadır. Atık su ayrıca kan, iç organ, kemik, idrar ve dışkı, kesim ve kesme sırasında çıkarılan yumuşak dokuları, deri ve tırnak kaynaklı toprak, erimiş yağ ve temizleme ve dezenfektan bileşiklerini kapsamaktadır ${ }^{22}$. Bununla birlikte, Salmonella spp., Campylobacter spp. ve 
L.monocytogenes gibi gastroenteritlerin en önemli etkenleri olan bakteriyel patojenlerin, kesimhane atık suyundan izole edildiği bildirilmiştir ${ }^{23}$. Kesimhane atık suları yakınındaki içme su kaynaklarına sızarak onları da kontamine etmekte, bu vesile ile içme suyu vasıtasıyla insanlarda ve hayvanlarda Campylobacter enfeksiyonlarına neden olmaktadır ${ }^{24}$. Çalışmamızda izolatların büyük bir kısmı (11, \%7.3) kesimhane atık suyundan elde edilmiştir. Bu çalışma sonuçlarına benzer şekilde Elmalı ve Can'ın bildirdikleri çalışmada², incelenen 78 atık su örneğinden, 8 (\%10.3) Campylobacter spp. izolasyonu yapılmıştır. Kesimhane atık sularında Campylobacter'lerin izole edilmiş olması, etkenin çevresel kontaminasyondan sorumlu olabileceğinin en önemli göstergesidir².

Sığırlar, Campylobacter'lerin muhtemel asemptomatik taşıyıcılarıdır; bu nedenle kesim sürecinde hayvanın dışkısından, kesim sırasında farklı hayvanlardan ya da kesimde kullanılan kontamine alet ve ekipmandan karkası kontamine edebildikleri bildirilmiştir ${ }^{25}$.

Kesimhanelerde karkasla temas eden yüzeylere ilişkin sınırlı sayıda yayına ulaşılmıştır. Çalışmamızda kesimhanelerden ayrılan C.jejuni'lerden 1 (\%5.9)'i bıçak örneklerinden izole edilmiştir. Ayalew ve arkadaşlarının ${ }^{26}$ bildirdiği bir çalışmada kesim tahtaları ve bıçaklarda Campylobacter varlığı saptanamamıştır. Bıçak gibi karkas dışındaki kesimhane materyallerinde Campylobacter türlerinin varlığı kullanılan alet ve malzemelerde gerekli hijyenik tedbirlerin yeterince uygulanmadığının ve kontaminasyon varlığının bir göstergesidir.

Çalışmamızda C.jejuni izolatlarının tamamı kinolon grubu antibiyotiklerden siprofloksasine ve \%87.5'i enrofloksasine dirençliyken, C.fetus izolatlarının \%87.5'i siprofloksasine ve enrofloksasine duyarlı bulunmuştur. C.coli izolatı ise orta duyarlı olarak tespit edilmiştir. Wieczorek ve arkadaşlarının çalışmasında ${ }^{18}$ siprofloksasin direnci C.jejuni izolatları için \%29.4 ve C.coli izolatları için \%51.1 olarak tespit edilmiştir. Adıgüzel ve arkadaşlarının çalışmalarında ${ }^{27}$ siprofloksasin direnci, C.jejuni izolatları için \%87.8, C.coli izolatlarında ise $\% 98.8$ oranında bulunmuştur. Kayman ve arkadaşlarının çalışmasında ${ }^{28}$ insanlardan elde edilen C.jejuni izolatlarının \%74.3'ü siprofloksasine dirençli olarak tespit edilmiştir. Elmalı ve $\mathrm{Can}^{2}$ C.jejuni izolatlarının \%50'sini, C.coli izolatlarının ise tamamını siprofloksasine dirençli olarak bildirmişlerdir. Maktabi ve arkadaşlarının çalışmasında ${ }^{3}$ enrofloksasine düşük oranda (\%6.2) direnç gösterilmiştir. Farklı olarak Turgay ve Bozdoğan'ın bildirdikleri çalışmada ${ }^{4}$ C.jejuni ve C.coli izolatlarının tamamı siprofloksasine duyarlı bulunmuştur. Ülkemizden ve çeşitli ülkelerden yapılmış çalışmalarda yüksek siprofloksasin direnci ortaya konmuştur. Bu durum tedavide siprofloksasin kullanımının azaltılması gerekliliğini vurgulamaktadır.

Çalışmamızda C.jejuni izolatlarının yalnız 1 (\%12.5)'inde eritromisin direnci tespit edilmiştir. Çalışmamıza benzer şekilde Kayman ve arkadaşlarının çalışmasında ${ }^{28}$ C.jejuni izolatlarının \%5.9'unda eritromisin direnci saptanmıştır. Wieczorek ve arkadaşlarının çaIışmasında ${ }^{18}$ eritromisin direnci \%4.3 (C.jejuni, $\mathrm{n}=1$ ve C.coli, $\mathrm{n}=4$ ) olarak bildirilmiştir. Adıgüzel ve arkadaşları ${ }^{27}$ ile Turgay ve Bozdoğan'ın ${ }^{4}$ çalışmalarında izolatların tamamı eritromisine duyarlı bulunmuştur. Çalışmamızdan farklı olarak, Elmalı ve Can'ın yaptığı 
çalışmada ${ }^{2}$ eritromisin direnci \%71.4 oranında tespit edilmiştir. Bu çalışmada ${ }^{2}$ yüksek direnç rapor edilmiş olsa da daha önce yapılan çalışmaları ${ }^{4,18,28}$ büyük bir kısmında çalışmamıza benzer şekilde düşük eritromisin direncinden bahsedilmektedir.

Çalışmamızda, C.jejuni ve C.coli izolatlarının tamamı, C.fetus izolatlarının ise $\% 87.5^{\prime} \mathrm{i}$ gentamisine duyarlı bulunmuştur. C.fetus izolatlarının sadece 1 (\%12.5)'inde gentamisin direnci saptanmıştır. Wieczorek ve arkadaşlarının yaptığı çalışmada ${ }^{18}$ gentamisin direnci \%2.6 (C. jejuni, $\mathrm{n}=1$ ve C.coli, $\mathrm{n}=2$ ) olarak bulunmuştur. Benzer şekilde, Maktabi ve arkadaşlarının ${ }^{3}$ ve Turgay ve Bozdoğan'ın ${ }^{4}$ yaptıkları çalışmalarda izolatların tamamı gentamisine duyarlı bulunmuştur.

Çalışmamızda araştıılan virülans genlerinden virB11, izolatların hiçbirinde tespit edilememiştir. Bununla birlikte, iam geni C.fetus ve C.coli izolatlarında bulunmazken yalnız 1 (\%12.5) C.jejuni izolatında bu gen saptanmıştır. $c d t A, c d t B$, ceuE ve cadF genleri, C.jejuni izolatlarının tamamında pozitif bulunmuştur. Wieczorek ve arkadaşlarının yaptığı çalışma$\mathrm{da}^{18}$ izolatların çoğunluğu $c a d F$ ve flaA genlerine sahipken, daha az kısmında ise iam ve virB11 genleri saptanmıştır. Çalışmada $c d t A, c d t B$ ve $c d t C$ genleri $C$.jejuni izolatlarının tamamında pozitif olarak belirlenmiştir. C.coli, 47 izolatın sadece 8 (\%17)'inde $c d t A, c d t B$ ve cdtC genleri pozitif olarak elde edilmiştir. Datta ve arkadaşlarının yaptığı çalışmada ${ }^{6}$, çalışmamızdan farklı olarak insan, kanatı ve sığır kökenli C.jejuni izolatlarının tamamında, flaA, $c a d F, c d t A, B$ ve $c d t C$ geni bulunmuştur. Elmalı ve Can'ın yaptıkları çalışmada ${ }^{2}$, C.jejuni izolatlarının \%66.6 ve \%41.6'sında sırasıyla $c d t A$ ve $c a d F$ virülans genleri tespit edilmiştir. Wieczorek'in çalışmasında ${ }^{29}$, çalışmamızdan farkı olarak, tüm sığır kökenli Campylobacter'lerde $f l a A$ ve $c a d F$ genleri tespit edilirken, izolatların büyük bir kısmında $c d t A$, $c d t B$ ve $c d t C$ gibi toksin genleri ve iam bulunmuştur. Çalışmamızda ise iam geni C.fetus ve C.coli izolatlarında saptanmazken yalnız 1 (\%12.5) C.jejuni izolatında tespit edilmiştir. Çalışmamızın aksine, virB11 geni, Wieczorek'in bildirdiği çalışmada ${ }^{29}$ izolatların \%12.5'inde bulunmuştur. Campylobacter'lerin patojenitesinden sorumlu genler, adezyon, invazyon, kolonizasyon ve sitotoksin üretiminden sorumludur ve hastalığın klinik ve epidemiyolojik özellikleri Campylobacter enfeksiyonlarında rol oynayan moleküler mekanizmalar hakkında ipuçları sağlamaktadır 6 .

İolatların klonal yakınlıklarının belirlenmesi amacıyla ERIC-PCR yapılmış ve Campylobacter izolatlarının bant profillerinin birbirinden farklı olduğu saptanmıştır. Bant sayısının 2 ile 11 arasında değiştiği ortaya konmuştur. Çalışmada kullandığımız, ERIC-PCR, nispeten yüksek bir ayırt edici güce sahip olup, aynı zamanda kolay ve hızlı olmanın yanı sıra düşük maliyetlidir ${ }^{29}$. Wieczorek'in bildirdiği çalışmada ${ }^{29}$, ERIC-PCR profillerinden üretilen dendrograma dayalı filogenetik analizde C.jejuni ve C.coli izolatlarının üç kümeye ait olduğu gösterilmiştir. Çalışmamızda küme analizi yapılmamış ve izolatların bant profilleri şematik olarak gösterilmiştir. Ayrıca, çalışmamızda C.jejuni izolatları ile C.jejuni ve C.fetus izolatları ile C.fetus izolatlarının birbirleriyle klonal yönden benzerlik gösterdiği ve aynı klonlar içerisinde yer aldığı ortaya çıkmıştı. Ek olarak, bazı C.jejuni izolatları ile C.fetus ve C.coli ile C.fetus izolatlarının benzerlik gösterdiği belirlenmiştir. 
Farklı Kesimhanelerden İzole Edilen Campylobacter Türlerinin Virülans Genleri,

Antibiyotik Duyarlılık Profilleri ve Moleküler Karakterizasyonu

Sonuç olarak, bu çalışmada kesimhanelerden izole edilen Campylobacter izolatlarının güncel antibiyotiklerin bir çoğuna dirençli olduğu ortaya konmuştur. Kesimhane ortamında özellikle kesimhane atık suyunda yüksek virülans özelliklerine sahip Campylobacter türlerinin bulunması, karkaslar ve dolayısıyla gıdalar aracılığıyla insanlara bulaşma riskinden dolayı halk sağlığı açısından göz ardı edilemez bir tehlike oluşturabileceği açıktır. Bu nedenle, kesimhanelerde Campylobacter türlerinin azaltılması ve bunlara bağlı enfeksiyonların önlenmesi için halihazırda uygulanan hayvansal gıdalar için özel hijyen kurallarına uyulması ve gerekli durumlarda denetimlerin artırılması önerilmektedir.

\section{TEŞEKKÜR}

Erciyes Üniversitesi Veteriner Fakültesi, Biyometri Anabilim Dalı Öğretim Üyesi, Doç. Dr. Aytaç Akçay'a çalışmamızın istatistiksel analiz kısmına katkılarından dolayı ve makalenin Ingilizce özet kısmının kontrol edilmesinde ve düzenlenmesinde katkılarından dolayı Erciyes Üniversitesi Bilimsel Metin Destekleme Ofisine (Proofreading\& Editing Office) teşekkür ederiz.

\section{ÇIKAR ÇATIŞMASI}

Yazarlar bu makale ile ilgili herhangi bir çıkar çatışması bildirmemişlerdir.

\section{KAYNAKLAR}

1. Bailey GD, Vanselow BA, Hornitzky MA, Hum SI, Eamens GJ, Gill PA, et al. A study of the foodborne pathogens: Campylobacter, Listeria and Yersinia, in faeces from slaughter-age cattle and sheep in Australia. Commun Dis Intell Q Rep 2003;27(2):249-57.

2. Elmalı M, Can HY. Antimicrobial susceptibility and virulence-associated genes in Campylobacter isolates from milk and wastewater in Hatay, Turkey. Ciência Rural 2019;49(5):e20180227.

3. Maktabi S, Ghorbanpoor M, Hossaini M, Motavalibashi A. Detection of multi-antibiotic resistant Campylobacter coli and Campylobacter jejuni in beef, mutton, chicken and water buffalo meat in Ahvaz, Iran. Vet Res Forum 2019;10(1):37-42.

4. Turgay Ö, Bozdoğan H. Kırmızı ette Campylobacter türlerinin varlı̆̆ı ve antibiyotik dirençliliğinin belirlenmesi. KSÜ Doğa Bil Derg 2011;14(3):5-8.

5. Kayman T, Abay S, Hızlısoy H. Campylobacter türlerinin fenotipik yöntemler ve multipleks polimeraz zincir reaksiyonu ile tanımlanması ve antibiyotik duyarlııkları. Mikrobiyol Bul 2013;47(2):230-9.

6. Datta S, Niwa H, Itoh K. Prevalence of 11 pathogenic genes of Campylobacter jejuni by PCR in strains isolated from humans, poultry meat and broiler and bovine faeces. J Med Microbiol 2003;52(Pt 4):345-8.

7. ISO 10272. Microbiology of food and animal feeding stuffs-horizontal method for detection of thermotolerant Campylobacter. The International Organization for Standardization 1995.

8. Wang G, Clifford GC, Tracy MT, Pucknell C, Barton C, Price L, et al. Colony multiplex PCR assay for identification and differentiation of Campylobacter jejuni, C.coli, C.lari, C.upsaliensis, and C.fetus subsp. fetus. I Clin Microbiol 2002;40(12):4744-7.

9. Clinical and Laboratory Standards Institute (CLSI). Clinical and Laboratory Standards Institute performance standards for antimicrobial susceptibility testing; Twenty-Fourth Informational Supplement, 2014; M100-S 24, Wayne PA.

10. Krutkiewicz A, Klimuszko D. Genotyping and PCR detection of potential virulence genes in Campylobacter jejuni and Campylobacter coli isolates from different sources in Poland. Folia Microbiol (Praha) 2010;55(2):167-75. 
11. Chansiripornchai N, Sasipreeyajan J. PCR detection of four virulence-associated genes of Campylobacter jejuni isolates from Thai broilers and their abilities of adhesion to and invasion of INT-407 cells. J Vet Med Sci 2009;71(6):839-44.

12. Ripabelli G, Tamburro M, Minelli F, Leone A, Sammarco ML. Prevalence of virulence-associated genes and cytolethal distending toxin production in Campylobacter spp. isolated in Italy. Comp Immunol Microbiol Infect Dis 2010;33(4):355-64.

13. Houf K, De Zutter L, Van Hoof J, Vandamme P. Assessment of the genetic diversity among Arcobacters isolated from poultry products by using two PCR-based typing methods. Appl Environ Microbiol 2002;68(5):2172-8.

14. Viswanathan M, Pearl DL, Taboada EN, Parmley EJ, Mutschall SK, Jardine CM. Cluster Analysis of Campylobacter jejuni genotypes isolated from small and medium-sized mammalian wildlife and bovine livestock from Ontario farms. Zoonoses Public Health 2017;64(3):185-93.

15. Letunic I, Bork P. Interactive tree of life (iTOL) v4: recent updates and new developments. Nucleic Acids Res 2019: 47(W1):W256-9.

16. SPSS Statistical Package for Windows, Version 14.0.1, (Serial: 9869264). SPSS Inc. Chicago, USA, 2001.

17. Wieczorek K, Osek J. Occurrence of Campylobacter on carcasses of slaughtered animals between 2009 and 2013. Bull Vet Inst Pulawy 2014;58(4):553-8.

18. Wieczorek K, Kania I, Osek J. Prevalence and antimicrobial resistance of Campylobacter spp. isolated from poultry carcasses in Poland. J Food Prot 2013;76(8):1451-5.

19. Rahimi E, Momtaz H, Hemmatzadeh F. The prevalence of Escherichia coli O157:H7, Listeria monocytogenes and Campylobacter spp. on bovine carcasses in Isfahan, Iran. Iran J Vet Res 2008;9(4):365-70.

20. Nonga HE, Sells P, Karimuribo ED. Occurrences of thermophilic Campylobacter in cattle slaughtered at Morogoro municipal abattoir, Tanzania. Trop Anim Health Prod 2010;42(1):73-8.

21. Wagenaar JA, Van Bergen Map, Blaser MJ, Tauxe RV, Newell DG, Van Putten JPM. Campylobacter fetus infections in humans. exposure and disease. Clin Infect Dis 2014;58(11):1579-86.

22. Yildirim NC, Tanyol M, Serdar O, Yildirim N. Gammarus pulex as a model organism to assess the residual toxicity of slaughterhouse wastewater treated by electrocoagulation process. Bull Environ Contam Toxicol 2019;103(3):447-52.

23. Nafarnda WD, Ajayi IE, Shawulu JC, Kawe MS, Omeiza GK, Sani NA, et al. Bacteriological quality of abattoir effluents discharged into water bodies in Abuja, Nigeria. ISRN Vet Sci 2012;e515689.

24. Trigui H, Thibodeau A, Fravalo P, Letellier A, Faucher SP. Survival in water of Campylobacter jejuni strains isolated from the slaughterhouse. Springerplus 2015;4(1):799.

25. Kashoma IP, Kassem II, John J, Kessy BM, Gebreyes W, Kazwala RR, et al. Prevalence and antimicrobial resistance of Campylobacter isolated from dressed beef carcasses and raw milk in Tanzania. Microb Drug Resist 2016; 22(1):40-52.

26. Ayalew H, Berhanu A, Sibhat B, Serda B. Microbiological assessment of meat contact surfaces at abattoir and retail houses in Jigjiga town, Somali National Regional State of Ethiopia. ISAAB J Food Sci 2015;5(3):21-6.

27. Adiguzel MC, Sigirci BD, Celik B, Kahraman BB, Metiner K, Ikiz S, et al. Phenotypic and genotypic examination of antimicrobial resistance in thermophilic Campylobacter species isolated from poultry in Turkey. J Vet Res 2018;62(4):463-8.

28. Kayman T, Abay S, Aydin F, Şahin O. Antibiotic resistance of Campylobacter jejuni isolates recovered from humans with diarrhoea in Turkey. J Med Microbiol 2019;68(2):136-42.

29. Wieczorek K. Relationship between the molecular typing of Campylobacter strains and the prevalence of their virulence genes. Bull Vet Inst Pulawy 2009;53(2):193-8. 